Article

\title{
Enterprise Activity Modeling in Walnut Sector in Ukraine
}

\author{
Vitalii Lutsiak $^{1}{ }^{(\mathbb{D}}$, Taras Hutsol ${ }^{2, *(\mathbb{D})}$, Nataliia Kovalenko ${ }^{1} \mathbb{D}$, Dariusz Kwaśniewski ${ }^{3}$, Zbigniew Kowalczyk ${ }^{3}$,D \\ Svitlana Belei $^{4}$ and Tatiana Marusei ${ }^{5}$
}

1 Department of Administrative Management and Foreign Economic Activity, National University of Life and Environmental Sciences of Ukraine, 03041 Kyiv, Ukraine; lutsiakvv@nubip.edu.ua (V.L.); nperederiy@nubip.edu.ua (N.K.)

2 Department of Mechanics and Agroecosystems Engineering, Polissia National University, 10008 Zhytomyr, Ukraine

3 Department of Production Organization, Logistics and Applied Computer Science, University of Agriculture in Krakow, 30239 Krakow, Poland; dariusz.kwasniewski@urk.edu.pl (D.K.); zbigniew.kowalczyk@urk.edu.pl (Z.K.)

4 Department of Accounting and Taxation, Yuriy Fedkovych Chernivtsi National University, 58012 Chernivtsi, Ukraine; s.belei@chnu.edu.ua

5 Department of Tourism and Hotel and Restaurant Business, Ivan Ogiyenko Kamyanets-Podilsky National University, 32301 Kamyanets-Podilsky, Ukraine; nikmar@gmail.com

* Correspondence: wte.inter@gmail.com

Citation: Lutsiak, V.; Hutsol, T.; Kovalenko, N.; Kwaśniewski, D.; Kowalczyk, Z.; Belei, S.; Marusei, T. Enterprise Activity Modeling in Walnut Sector in Ukraine. Sustainability 2021, 13, 13027. https://doi.org/10.3390/ su132313027

Academic Editor: Mario D'Amico

Received: 18 October 2021

Accepted: 19 November 2021

Published: 24 November 2021

Publisher's Note: MDPI stays neutral with regard to jurisdictional claims in published maps and institutional affiliations.

Copyright: (c) 2021 by the authors. Licensee MDPI, Basel, Switzerland. This article is an open access article distributed under the terms and conditions of the Creative Commons Attribution (CC BY) license (https:// creativecommons.org/licenses/by/ $4.0 /)$.

\begin{abstract}
The main goal of this study was to provide a critical analysis of the oil and fat sub-complex for deep walnut processing, to determine and compare the profitability of enterprises' activities under different business models for implementation in the agro-food value chain. The latter was considered as an important factor for the development of the domestic market of walnuts and export opportunities. Business modeling of the enterprise activity in the oil and fat sub-complex for deep walnut processing was carried out. The stages of production and marketing activities of the enterprise from the garden planting or the purchase of the processed raw materials to the sale of the processed raw materials and products obtained from walnut processing depending on the chosen business model were considered. A comparative analysis of profitability of the enterprise activity and absolute values of income and profitability indicators under various business models of the enterprise activity were shown. The most cost-effective business-model entailed the combination of walnut production and its processing, which will provide profitability of up to $4640.32 \%$ in the 20th year of the project implementation. The results of the given study are intended for the agricultural enterprises of central region of Ukraine.
\end{abstract}

Keywords: business model; profitability; walnut production; walnut processing; comparative analysis

\section{Introduction}

In the context of global climate change and through new trends in the agri-food market, over the past two decades, there has been a tangible increase in the demand for the production and consumption of nuts. Official data testifies to the relevance of growing nuts. Thus, according to the annual report of the International Nut and Dried Fruit Council Foundation (INC) over the past 10 years, global nut production has grown steadily and in the 2019/20 financial year amounted to 4,600,000 $\mathrm{t}$ [1].

The main types of nuts include the so-called "Big Five": walnuts, almonds, pistachios, cashews and hazelnuts. In terms of harvest, almonds and walnuts are the leaders, accounting for $31 \%$ and $21 \%$ of world production, respectively, followed by cashews (17\%), pistachios (14\%) and hazelnuts $(12 \%)$. The remaining $5 \%$ comes from the production of pecans, macadamias, Brazil nuts, and pine nuts [2].

Currently, walnut production in Ukraine is a profitable type of entrepreneurial activity at the level of farms, which appeared to be a systematic business in the country during the last years. The area of industrial walnut plantations in Ukraine is growing dynamically 
every year. According to the data of the Ukrainian Walnut Association, the most annual growth of walnut plantations in Ukraine falls on the creation of industrial hazelnut orchards and is more than 1000-1400 ha annually. The actual area of planted gardens in 2020 is about 3000 ha. Thus, in the central Ukraine region, there are a number of small farms that grow walnuts on 10-15 ha of land and perform their primary processing. Hence, since 2015 hundreds of hectares of modern, intensive gardens of walnuts and hazelnuts were planted using the technologies of inter-row planting until the garden reaches its estimated capacity. According to the International Nuts and Dried Fruit Council Foundation [1] the cost of the processed raw materials, i.e., walnut kernels, intended for further use in the agro-food chain, varies in the European market from 4 to $9 \mathrm{EUR} / \mathrm{kg}$. The cost of food products obtained due to walnut kernel processing in the oil and fat sub-complex reaches EUR30 per 1 of the packed walnut oil, and it may also increase by 5-10 EUR/ kg of walnut kernel if the cost of products obtained as a result of processing the waste of the main production is taken into account [1].

At the same time, the marketing of products of the oil and fat sub-complex for deep walnut processing in Ukraine and in its central region, in particular, is still much localized; producers have no direct access to foreign markets as well as they are not integrated in value chains. So that only small batches of produce are exported in a direct way. However, the international demand for edible oils and other food products obtained as a result of walnut processing is increasing, as SuperArgonom noticed [3]. According to SuperArgonom's data, every year Ukraine produces over 100,000 $\mathrm{t}$ of walnuts; two-thirds of this yield is exported. The world consumption of nuts shows a positive growth trend. According to INC, as of May 2018, the global number of nut consumers reached 1 billion, in 2030 it is predicted to increase to 1.8 billion, and in 2040, the number of nut consumers will double to 2.8 billion. Almonds and walnuts account for half of the total consumption of nuts in 2018 worldwide (30\% and $20 \%$ of the world share, respectively), the share of hazelnuts is $12 \%$. European countries consume $26 \%$ of the global share, followed by North America $(23 \%)$ and Asia (20\%) [3].

The Statista organization claimed that the global market for walnut oil is growing at a moderate pace due to its wide range of applications [2]. The world market for walnuts is rather specific, since the production remains extensive, and the area potentially suitable for land cultivation is limited, as a result walnuts may ripen normally on the territory that occupies $6-14 \%$ of the planet. The land resources of Ukraine are included in these statistics. According to the statistics presented by the International Nuts and Dried Fruit Council Foundation, Ukraine holds a strong position among the top ten largest exporters of nuts in the world [1]. Information on the imports and exports introduced by Tridge shows that Ukraine is a net exporter of oilseed crops and oils, refined edible oils, various wastes, residues, and other products [4].

Consequently, all the above mentioned demonstrate that Ukraine will be involved in the process of diversifying the world market of nuts, oils, and fats, as well as in the innovation process in the oil and fat sub-complex. Almost the entire territory of Ukraine has favorable climatic conditions and suitable soils for growing nuts and obtaining a high-quality product. Considering the duration of walnut orchards fruiting, as well as the fact that our state has more suitable areas for growing nuts than other countries, the rapid development of this area is absolutely justified. According to our observations, the oil and fat sub-complex for deep walnut processing is at the stage of formation and it is characterized by small production volumes (a small number of farmers growing industrial gardens), as well as few processing enterprises (several private entrepreneurs with a limited production capacity of 10 to 100 L per day). Income receipts are made by sole proprietors; however, cooperation between them is not established. The initiated study aims to offer a comprehensive and integrated business model for the development of the oil and fat sub-complex for deep processing of walnut. 


\section{Literature Review}

The study by and O. Lyulyov [5] illustrated that currently, researchers are greatly interested in the problems of environmental management, food security, development of new technologies and products of nut industry worldwide that are highlighted in a number of scientific papers. For instance, M. Kachel et al. studied the biodiesel production on the basis of selected oils of natural origin using [6]. R. Botta et al. devised the genetic tools in order to ensure the supply of hazelnut [7] that corresponds with multiple connected studies of the post-harvest practices [8], storability improvement [9], etc., in the given sector. Likewise, sustainable development and its prospects include a number of measures encouraging agricultural entrepreneurs to be involved in social activities [10].

There is a worldwide discussion about the possibilities of expanding the potential of the raw material base [11] of walnuts in particular [12], and the utilization of raw materials in the agro-food value chain to enhance the competitiveness of products. In the given sense there were different aspects studied: the development of the logistic strategies as well as the place and structure of logistic costs [13], eco-industrial parks maintenance, circular economy projects [14], savings in diverse segments of the supply chain [15], quality assessments of delivery [16] and many others. In particular, for the oil and fat sub-complex for deep walnut processing and the development of functional food products, the latest studies include: investigations on oil content in kernels [17], the effective use of the by-products of walnut production for the removal of hazardous materials [18,19], the researches on functional properties of walnut protein [20], production processes energy consumption [21], maintenance of the organized quality management systems [22] etc.

The sub-complex analysis (SA) is an effective approach to gain a full understanding about the different connected stages of product or service transition from the raw material base to production and to the final consumer $[23,24]$. SA and enterprise activity modeling are the sources of information for value chain stakeholders at different levels. E. M. Nang'ole et al. [25] provided a set of guidelines and manuals for the analysis of the agricultural value chain from the perspectives of SA. The PMC Research Center and Batumi Shota Rustaveli State University of the Autonomous Republic of Ajara in their report elaborated the in-depth description of walnut production and sales process [26]. The study of N. A. Qammer and S. H. Baba while discussing the modernized supply chain of walnut, has boiled down to the fact that the given chains involve heavy investments and that the value addition of walnut in the processing units are exclusively targeted for export markets [27]. W. Bourne studied the production and marketing conditions for walnut and underlined the great potential of walnut production and processing in terms of gross margin taken [28]. G. Pandey and S. K. Shukla dedicated their study to the walnut industry in India in the light of cultural practices, growing regions and marketing trends [29] that determines the multiple connections in the sub-complex of walnut production. A. Szelag-Sikora et al. provided the comparative analysis of the farm's production systems from the perspectives of the technologies implemented that allowed her to evaluate the different aspects of plant nutrients management [30]. Next, Shamra P. et al. investigated the walnut processing industry and the potential value of the added products that brought her to the point of quality procuring [31]. So, the versatile approach to the sub-complex analysis provides a number of opportunities for further researches. For this reason, the sub-complex can be determined by the raw material, that is processed by its enterprise, or by the end product/service intended for the certain market [32-36].

There was proposed the provision of economic substantiation of the expediency of planting industrial, intensive walnut gardens by the local researches. Their suggestions allowed for the peculiarities of indigenous grades of walnut trees, while focusing on possible yield [37-40]. It is equally important that there are a lot of different aspects of deep walnut processing that are considered widely and should be allowed for further researches, such as: walnut production technology $[41,42]$; genetic resources $[36,43,44]$; walnut peeling processes [45-47]; walnut processing waste valorization that emphasizes the high interest in providing technological non-waste processing considerations [48,49]. 


\section{Materials and Methods}

The general purpose of the research is providing critical analysis of the oil and fat sub-complex for deep walnut processing, to determine and compare the profitability of enterprises' activities under different models and implementation forms in the agro-food value chain, which will justify the development strategies of business entities. This work is part of a chronological and systematic study devoted to the problem aspects of the sub-complex in central Ukraine region, particularly in the perspective of the world and national dynamics. To analyze profitability at the farm level and the level of processors, a simplified gross margin or profitability is used. The analysis of profitability is based on the optimal indices of walnut yields in the central Ukraine region under different models.

Based on the analysis of expenses for the preparation, planting, and maintenance of the garden, we modelled the profitability of the farm according to different models concerning the business model. When analyzing farm profitability, a comparison is made. Modeling of profitability is carried out according to the models of farms' activities in the cases when they grow a fruit garden and sell walnut kernels, and when they process walnut kernel and sell oil in bulk and unprocessed walnut oilcake using the B2B business model. Cost-effectiveness of production (farm level): model 1, in which the farmer sells walnut kernel. Profitability (farm level): model 2 where a farmer sells walnut oil and oilcake. For this model, two implementation forms are possible: (1) when the farmer organizes the production of oil and oilcake at his own farm; (2) when the farmer provides raw materials for processing and receives the finished oil and oilcake. Each of these implementation forms may have its advantages and disadvantages, which should be taken into account in the process of decision-making on business organization. Profitability of production (farm level): model 3, when the processor buys walnut and sells oil and oilcake.

To analyze profitability at the farm level and the level of processors, a simplified gross margin or profitability was used [50-57]. The gross margin characterizes the ratio of the direct costs and gross profit to the selling price. The gross margin makes it easier to compare the results, since the results are presented in relative units. In addition, each model contains a number of related assumptions that are reflected in the results for convenience.

\section{Results}

In the modern market, walnuts can be used in two most common ways: (1) shelled fruits can be used for the production of seeds (2) unshelled fruits can be used for feeding domestic animals and birds, as well as for food production. As G. Mir, N. Owais, and I. Uzma [37] investigated, seeds of varieties of oilseed crops contain 50 to $70 \%$ of oil and up to $40 \%$ of protein. As a rule, a high-quality walnut has a relatively thin shell that remains freely attached to the kernel, which enables to grow fruits that are quite full of kernels. According to O. Bozhok and V. [12,58], low-quality walnut fruits are filled with kernels by $30-55 \%$, while high quality walnuts are filled by $45-55 \%$. Fruits of low-quality hybrids, as a rule, vary in size, filling fruits with kernels, shell thickness, and oil content.

The analysis of profitability is based on the optimal indices of walnut yields in the central Ukraine region under different models. According to the main model, the optimum walnut yield is achieved through the application of scientific and production practices. The yield of walnut is a function of two factors:

(1) Proper farming practice, such as planting schemes (density of trees in the garden), pollinators, establishing and pruning, crown formation, soil retention, pest and disease control, fertilization and irrigation, harvesting and post-harvesting [13,59,60].

(2) Genetic potential: zoned and selection varieties provide higher yields than wild varieties. However, they are characterized by higher inputs [12,61-65].

This research outlines walnut yields and productivity, as shown in Table 1. 
Table 1. Walnut yield capacity.

\begin{tabular}{ccc}
\hline $\begin{array}{c}\text { Garden Age, } \\
\text { (Years) }\end{array}$ & $\begin{array}{c}\text { Tree Density in the Garden, } \\
\text { Trees } \cdot \text { ha }^{-1}\end{array}$ & $\begin{array}{c}\text { Average Yield, } \\
\text { t.ha }\end{array}$ \\
\hline & up to 100 & up to 0.25 \\
$5-9$ & $100-125$ & 0.625 \\
& $125-150$ & up to 1 \\
\hline \multirow{2}{*}{$10-19$} & up to 100 & up to 1.5 \\
& $100-125$ & $15-2$ \\
& $125-150$ & $2-2.1$ \\
\hline \multirow{2}{*}{$20-100$} & up to 100 & up to 3 \\
& $100-125$ & $8-10$ \\
& $125-150$ & 10 and more \\
\hline
\end{tabular}

Sources: comprised by the authors according to $[12,39,40,54,66]$.

Table 1 presents the approximate average data that should be investigated under conditions of a particular farm, especially as the periods for which the yield data are given are conditional. Under proper garden maintenance and normal climatic conditions, it is expected that the yield of the garden will increase with each passing year. However, such data can be used for preliminary estimates of profitability of the value chain in the oil and fat sub-complex.

When analyzing farm profitability, a comparison is made. The modeling of profitability is carried out according to the models of farms' activities in the cases when they sell walnut kernel, and when they process walnut kernel and sell oil in bulk and unprocessed walnut oilcake using B2B business model.

Assumption 1 made when calculating costs of walnut production are as follows:

- Calculations were made for the scheme of walnut planting $10 \times 10 \mathrm{~m}$ (100 seedlings per hectare);

- Estimated cost of 1 high-quality seedling, which is zoned according to the local climatic conditions and begins to bear fruit starting from the 4th year of vegetation, EUR13;

- Land rent, 55 EUR/ha;

- Protection: the first two years, for 8 months, starting from the 5th year. for 3 months (during harvesting);

- Watering: 1 time $\times 3$ weeks $\times 30 \mathrm{~L}$;

- Period before fruiting lasts for 2 years.

The summarized calculations of farmers' expenses for walnut production on 10 ha of the garden before fruiting are shown in Table 2.

Table 2. General analysis of farmers' expenses for walnut production on 10 ha of the garden before fruiting.

\begin{tabular}{ccc}
\hline Item of Expenses & Amount, EUR & $\begin{array}{c}\text { Share of Expenses } \\
\text { in the General Structure, \% }\end{array}$ \\
\hline Wages with charges & 4.47 & 18.01 \\
Fuel & 1.82 & 7.35 \\
Saplings & 12.7 & 51.2 \\
Spraying & 0.59 & 2.36 \\
Mineral fertilizers & 1.22 & 4.94 \\
Organic fertilizers & 0.89 & 3.61 \\
Total & 3.11 & 12.53 \\
Other expenses (land rent, irrigation, etc.) & 24.8 & 100.0 \\
\hline
\end{tabular}

Source: adopted by the authors according to [12,39].

The summarized calculations of walnut production costs are shown in Table 3. 
Table 3. General analysis of maintenance of 10 ha of the garden before its fruiting.

\begin{tabular}{ccc}
\hline Technological Maintenance Operations & $\begin{array}{c}\text { Costs, } \\
\text { Thousand } \\
\text { EUR }\end{array}$ & $\begin{array}{c}\text { Share in the } \\
\text { General Amount, } \\
\text { \% }\end{array}$ \\
Pre-planting soil preparation & 1.47 & 5.8 \\
Tree planting & 13.73 & 54.0 \\
Maintenance of the plantations, 1st year of vegetation & 1.73 & 6.8 \\
Maintenance of the plantations, 2nd year of vegetation & 2.71 & 10.6 \\
Maintenance of the plantations, 3rd year of vegetation & 2.76 & 10.8 \\
Maintenance of the plantations, 4th year of vegetation & 3.04 & 12.0 \\
\hline Source: compiled by the authors on the basis of [12]. & &
\end{tabular}

Source: compiled by the authors on the basis of [12].

According to Table 3, during the first four years, the largest share of expenses is intended for planting walnut seedlings, which includes the cost of high-quality seedlings and the cost of their planting. The lowest costs are expected for pre-planting soil preparation and maintenance of seedling during the first year of vegetation.

Based on this analysis of expenses for the preparation, planting and maintenance of the garden, we modelled the profitability of the farm according to different models concerning the implementation forms.

\section{Statistical Analysis}

In order to provide the statistical analysis of the values of gross expenses, gross income, profit, profitability through the investigated timeframe, we carried out further stages:

- Summarizing all expenses (the structure of the expenses is covered in the assumptions 1 for the particular business model);

- For establishing the overall amount of expenses for the particular business model during the investigated timeframe, we calculated the expenses of the progressive total;

- Calculating the yield for each year of gardening until the 20th year allowing for the function (1) representing the yield of walnuts through the analyzed period;

- Calculating the gross income allowing for the assumptions 1 that correspond to the particular business model;

- For establishing the overall amount of the gross income for the particular business model during the investigated timeframe, we calculated the income of the progressive total;

- Calculating of the profit were provided by subtraction of the gross expenses from the gross profit;

- For establishing the overall amount of the profit for the particular business model during the investigated timeframe, we calculated the profit of the progressive total;

- The calculation of profitability was carried out through the division of the gross profit by the gross expenses. The obtained results were represented in $\%$.

Cost-effectiveness of production (farm level): model 1, in which the farmer sells walnut kernel.

Assumption 2:

- calculations are based on yields per hectare of land;

- the assumed tree density is 150 trees per hectare for the zoned variety of the low growing walnut;

- kernel output under its primary processing is $45 \%$;

- the selling price of $1 \mathrm{~kg}$ of walnut kernel is EUR4.76;

- the yield of the walnut garden changes by the exponential function according to the basic yield points corresponding to the age of the garden, for the data given in Table 1 $(0.625 \mathrm{t} / \mathrm{ha}$ for the garden aged from 2 to 9 years, $2 \mathrm{t} / \mathrm{ha}$ for the garden aged from 10 to 20 years and $10 \mathrm{t} / \mathrm{ha}$ for the garden aged over 20 years), this function will have the following form:

$$
y=0.4475 \times e^{0.1543 \cdot x}
$$


where $y$ is the yield of the garden, $x$ is the age of the garden. The reliability of approximation for this model is $R^{2}=0.9992$;

- expenses for sales and expenses for the primary walnut processing (calibration, shelling);

- profitability is calculated as the ratio of gross profit (item 6) to the aggregate expenses for planting and maintaining a walnut garden (item 2).

The results of the calculations (Table 4) show that, according to assumptions 2, in the 2nd year of the garden a positive profitability of $332.06 \%$ is achieved (item 9), and in the 3 rd year there is a return of all invested funds and profits from activities in the amount of EUR5900 is obtained (item 8).

Table 4. Analysis of the profitability of 10 ha of the garden when selling walnut kernel.

\begin{tabular}{|c|c|c|c|c|c|c|c|c|}
\hline $\begin{array}{l}\text { Year of the } \\
\text { Project Imple- } \\
\text { mentation }\end{array}$ & $\begin{array}{c}\text { Expenses, } \\
\text { Thousand } \\
\text { EUR }\end{array}$ & $\begin{array}{l}\text { Expenses of the } \\
\text { Progressive Total, } \\
\text { Thousand EUR }\end{array}$ & $\begin{array}{l}\text { Yield, } \\
\text { t/ha }\end{array}$ & $\begin{array}{l}\text { Income, } \\
\text { Thousand } \\
\text { EUR }\end{array}$ & $\begin{array}{l}\text { Income of the } \\
\text { Progressive Total, } \\
\text { Thousand EUR }\end{array}$ & $\begin{array}{l}\text { Profit, } \\
\text { Thousand } \\
\text { EUR }\end{array}$ & $\begin{array}{l}\text { Profit of the } \\
\text { Progressive Total, } \\
\text { Thousand EUR }\end{array}$ & $\begin{array}{c}\text { Profitability, } \\
\%\end{array}$ \\
\hline 1 year & 16.3 & 16.3 & 0.00 & 0.00 & 0.00 & -16.3 & -16.3 & -100 \\
\hline 2 years & 3.03 & 19.32 & 6.10 & 13.07 & 13.07 & 10.05 & -6.25 & 332.06 \\
\hline 3 years & 3.07 & 22.39 & 7.10 & 15.21 & 28.29 & 12.14 & 5.9 & 395.09 \\
\hline 4 years & 3.04 & 25.43 & 8.30 & 17.79 & 46.07 & 14.74 & 20.64 & 484.81 \\
\hline 5 years & 3.06 & 28.5 & 9.70 & 20.79 & 66.86 & 17.73 & 38.36 & 579.2 \\
\hline 6 years & 3.09 & 31.58 & 11.30 & 24.21 & 91.07 & 21.13 & 59.49 & 684.72 \\
\hline 7 years & 3.15 & 34.73 & 13.20 & 28.29 & 119.36 & 25.14 & 84.63 & 799.09 \\
\hline 8 years & 3.23 & 37.96 & 15.40 & 33 & 152.36 & 29.77 & 114.4 & 921.12 \\
\hline 9 years & 3.28 & 41.23 & 17.90 & 38.36 & 190.71 & 35.08 & 149.48 & 1070.78 \\
\hline 10 years & 3.35 & 44.58 & 20.90 & 44.79 & 235.5 & 41.44 & 190.92 & 1237.2 \\
\hline 11 years & 3.45 & 48.03 & 24.40 & 52.29 & 287.79 & 48.84 & 239.76 & 1416.57 \\
\hline 12 years & 3.67 & 51.7 & 28.50 & 61.07 & 348.86 & 57.4 & 297.16 & 1564.14 \\
\hline 13 years & 3.8 & 55.5 & 33.30 & 71.36 & 420.21 & 67.56 & 364.71 & 1779.39 \\
\hline 14 years & 3.94 & 59.44 & 38.80 & 83.14 & 503.36 & 79.2 & 443.92 & 2010.39 \\
\hline 15 years & 4.09 & 63.53 & 45.30 & 97.07 & 600.43 & 92.98 & 536.9 & 2274.03 \\
\hline 16 years & 4.25 & 67.78 & 52.80 & 113.14 & 713.57 & 108.89 & 645.79 & 2561.69 \\
\hline 17 years & 4.43 & 72.21 & 61.70 & 132.21 & 845.79 & 127.79 & 773.58 & 2885.48 \\
\hline 18 years & 4.62 & 76.82 & 71.90 & 154.07 & 999.86 & 149.46 & 923.04 & 3237.86 \\
\hline 19 years & 4.81 & 81.63 & 83.90 & 179.79 & 1179.64 & 174.97 & 1098.01 & 3635.65 \\
\hline 20 years & 5.03 & 86.66 & 98.00 & 210 & 1389.64 & 204.97 & 1302.98 & 4078.77 \\
\hline
\end{tabular}

The average profitability increases after reaching its positive value of $233 \%$ per year up to the age of 20 , and it reaches the value of $4100 \%$ in the 20 th year of the garden. The function of changing the garden profitability by the based assumptions 2 is as follows:

$$
y=-9 \times 10^{-7} \times x^{2}+0.0083 \times x+0.9548
$$

where $y$ is profitability of the walnut garden, $x$ is the age of the walnut garden. The reliability of the approximation for this model is $R^{2}=0.9975$. The graphic is shown in Figure 1.

Profitability (farm level): model 2 where a farmer sells walnut oil and oilcake. For this model, two implementation forms are possible: (1) when the farmer organizes the production of oil and oilcake at his own farm; (2) when the farmer provides raw materials for processing and receives the finished oil and oilcake. Each of these business models may have its advantages and disadvantages, which should be taken into account in the process of decision-making on business organization. The first implementation form involves the organization of a special production unit at the farm, which must specialize in the processing of walnut kernel into oil and oilcake Thus, when modeling the profitability of walnut production, additional costs associated with this should be taken into account (Table 5). 


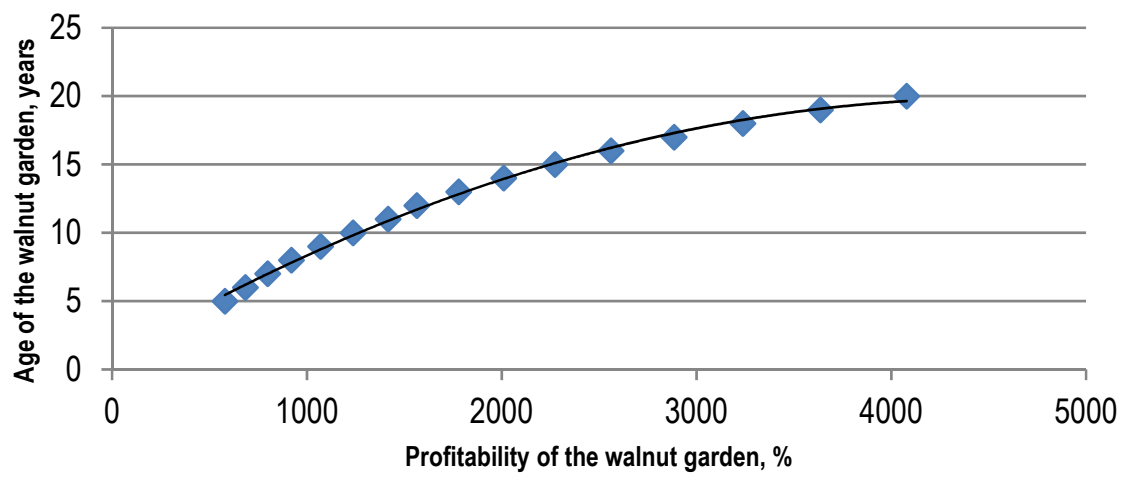

Figure 1. Change in the profitability of the walnut garden. Source: compiled by the authors on the basis of [38].

Table 5. General analysis of costs for oil production from walnut kernel.

\begin{tabular}{lcc}
\hline & Item of Expenses & Amount \\
\hline Basic expenses & & \\
Purchase of equipment and its introduction into operation & EUR8600 \\
Overheads & Wages with charges & EUR3200 \\
& Production costs & 3800 EUR/year \\
& 10 EUR/t \\
\hline Source: authors' development. &
\end{tabular}

Assumption 3.1:

- Equipment costs involve the purchase, transportation, customs clearance and installation of the basic production equipment and include the cost and installation of the auxiliary production equipment;

- Wages are calculated in the form of a single rate of monthly salary, regardless of the volume of production;

- Production costs include electricity costs (tariff of $0.06 \mathrm{EUR} / \mathrm{kW}$ ), $10 \mathrm{EUR} / \mathrm{t}$ of walnut kernel, materials and tools;

- Organization expenses include the costs for meeting the requirements of the control services and obtaining permit documents for production.

Assumption 3.2:

- Calculations are based on the data concerning the expenses;

- Investments in the production of walnut kernel products are made in the second year of business operation and garden growth;

- Oil output from walnut kernel is $42 \%$;

- The cost of processing walnut kernel into oil and oilcake is $0.57 \mathrm{EUR} / \mathrm{kg}$ of walnut kernel;

- The output of oilcake in oil production is $48 \%$;

- The selling price of $1 \mathrm{~kg}$ of walnut oil is EUR19;

- The selling price of $1 \mathrm{~kg}$ of walnut oilcake is $0.63 \mathrm{EUR} / \mathrm{kg}$ (Table 6).

The results of the calculations (Table 6) show that, according to Assumptions 3.1.and 3.2 , in the 2nd year of the garden, a positive profitability of $17.96 \%$ is reached (item 9), while in the 3rd the return of all invested funds and profits from activities in the amount of EUR5690 is achieved (item 8). The average profitability increases after reaching its positive value of $282 \%$ per year until the age of 20 , and it reaches the value of $4640 \%$ in the 20th year of the garden (item 9). At the same time, the production of walnut oil and oilcake from walnut kernels ensures the profitability of the garden from the first year of fruiting. The second implementation form of the model where a farmer sells walnut oil and oilcake requires outsourcing support for walnut production, which involves paying for walnut processing into the products with the added value by a specialized processor (Table 7). 
Table 6. Analysis of profitability of 10 ha of the garden when selling walnut oil and oilcake.

\begin{tabular}{|c|c|c|c|c|c|c|c|c|}
\hline $\begin{array}{l}\text { Year of the } \\
\text { Project } \\
\text { Implementa- } \\
\text { tion }\end{array}$ & $\begin{array}{c}\text { Expenses, } \\
\text { Thousand } \\
\text { EUR }\end{array}$ & $\begin{array}{l}\text { Expenses of the } \\
\text { Progressive } \\
\text { Total, Thousand } \\
\text { EUR }\end{array}$ & $\begin{array}{l}\text { Yield, } \\
\text { t/ha }\end{array}$ & $\begin{array}{l}\text { Income, } \\
\text { Thousand } \\
\text { EUR }\end{array}$ & $\begin{array}{l}\text { Income of the } \\
\text { Progressive Total, } \\
\text { Thousand EUR }\end{array}$ & $\begin{array}{l}\text { Profit, } \\
\text { Thousand } \\
\text { EUR }\end{array}$ & $\begin{array}{l}\text { Profit of the } \\
\text { Progressive Total, } \\
\text { Thousand EUR }\end{array}$ & $\begin{array}{c}\text { Profitability, } \\
\%\end{array}$ \\
\hline 1 year & 16.3 & 16.3 & 0 & 0 & 0 & -16.3 & -16.3 & -100 \\
\hline 2 years & 18.62 & 34.91 & 6.1 & 21.96 & 21.96 & 3.34 & -12.95 & 17.96 \\
\hline 3 years & 6.92 & 41.83 & 7.1 & 25.56 & 47.52 & 18.64 & 5.69 & 269.2 \\
\hline 4 years & 6.93 & 48.76 & 8.3 & 29.88 & 77.4 & 22.95 & 28.64 & 331.17 \\
\hline 5 years & 6.94 & 55.7 & 9.7 & 34.92 & 112.32 & 27.98 & 56.62 & 403.32 \\
\hline 6 years & 6.95 & 62.65 & 11.3 & 40.68 & 153 & 33.73 & 90.35 & 485.57 \\
\hline 7 years & 6.96 & 69.61 & 13.2 & 47.52 & 200.52 & 40.56 & 130.91 & 582.96 \\
\hline 8 years & 6.97 & 76.58 & 15.4 & 55.44 & 255.96 & 48.47 & 179.38 & 695.35 \\
\hline 9 years & 6.98 & 83.56 & 17.9 & 64.44 & 320.4 & 57.46 & 236.84 & 822.57 \\
\hline 10 years & 7 & 90.56 & 20.9 & 75.24 & 395.64 & 68.24 & 305.08 & 974.56 \\
\hline 11 years & 7.02 & 97.59 & 24.4 & 87.84 & 483.48 & 80.82 & 385.89 & 1150.93 \\
\hline 12 years & 7.05 & 104.63 & 28.5 & 102.6 & 586.08 & 95.55 & 481.45 & 1356.27 \\
\hline 13 years & 7.07 & 111.7 & 33.3 & 119.88 & 705.96 & 112.81 & 594.26 & 1594.94 \\
\hline 14 years & 7.1 & 118.81 & 38.8 & 139.68 & 845.64 & 132.58 & 726.83 & 1866.15 \\
\hline 15 years & 7.14 & 125.95 & 45.3 & 163.08 & 1008.72 & 155.94 & 882.77 & 2183.59 \\
\hline 16 years & 7.18 & 133.13 & 52.8 & 190.08 & 1198.8 & 182.9 & 1065.67 & 2545.79 \\
\hline 17 years & 7.24 & 140.37 & 61.7 & 222.12 & 1420.92 & 214.88 & 1280.55 & 2970.03 \\
\hline 18 years & 7.29 & 147.66 & 71.9 & 258.84 & 1679.76 & 251.55 & 1532.1 & 3448.96 \\
\hline 19 years & 7.36 & 155.03 & 83.9 & 302.04 & 1981.8 & 294.68 & 1826.77 & 4002.71 \\
\hline 20 years & 7.44 & 162.47 & 98 & 352.8 & 2334.6 & 345.36 & 2172.13 & 4640.32 \\
\hline
\end{tabular}

Source: compiled by the authors.

Table 7. General analysis of expenses for the payment of services for production of oil and oilcake from walnut kernel.

\begin{tabular}{|c|c|}
\hline Item of Expenses & Amount \\
\hline \multicolumn{2}{|l|}{ Basic expenses } \\
\hline Organization expenses & 320 EUR \\
\hline \multicolumn{2}{|l|}{ Overheads } \\
\hline $\begin{array}{l}\text { Payment for services for the walnut kernel processing } \\
\text { Total }\end{array}$ & $320 \mathrm{EUR} / \mathrm{t}$ \\
\hline
\end{tabular}

Assumption 4.1:

- Organization expenses may consist of expenses for ensuring the conditions for the implementation of the signed contract for the walnut kernel processing into oil and oilcake;

- Payment of the services for the walnut kernel processing includes payment for the transportation of raw materials and products of its processing, cargo loading services, preparation of raw materials for the processing, packaging, laboratory examination of the quality of obtained products, other production costs included in the processing of walnut kernel into oil and oilcake.

Assumption 4.2:

- Conditions for product storage are provided at the farm; however, expenses for the given measures do not have a significant impact on the changes in the profitability and income of the project;

- Contractual production of walnut oil and oilcake does not require additional investments (Table 8). 
Table 8. Analysis of profitability of 10 ha of the garden under outsourcing processing of walnut into oil and oilcake.

\begin{tabular}{|c|c|c|c|c|c|c|c|c|}
\hline $\begin{array}{l}\text { Year of the } \\
\text { Project } \\
\text { Implementa- } \\
\text { tion }\end{array}$ & $\begin{array}{c}\text { Expenses, } \\
\text { Thousand } \\
\text { EUR }\end{array}$ & $\begin{array}{l}\text { Expenses of the } \\
\text { Progressive Total, } \\
\text { Thousand EUR }\end{array}$ & $\begin{array}{l}\text { Yield, } \\
\text { t/ha }\end{array}$ & $\begin{array}{l}\text { Income, } \\
\text { Thousand } \\
\text { EUR }\end{array}$ & $\begin{array}{l}\text { Income of the } \\
\text { Progressive Total, } \\
\text { Thousand EUR }\end{array}$ & $\begin{array}{l}\text { Profit, } \\
\text { Thousand } \\
\text { EUR }\end{array}$ & $\begin{array}{l}\text { Profit of the } \\
\text { Progressive Total, } \\
\text { Thousand EUR }\end{array}$ & $\begin{array}{c}\text { Profitability, } \\
\%\end{array}$ \\
\hline 1 year & 16.30 & 16.30 & 0.00 & 0.00 & 0.00 & -16.30 & -16.30 & -100.00 \\
\hline 2 years & 3.90 & 20.19 & 6.10 & 21.96 & 21.96 & 18.06 & 1.77 & 463.54 \\
\hline 3 years & 4.09 & 24.28 & 7.10 & 25.56 & 47.52 & 21.47 & 23.24 & 525.35 \\
\hline 4 years & 4.26 & 28.54 & 8.30 & 29.88 & 77.40 & 25.62 & 48.86 & 601.62 \\
\hline 5 years & 4.46 & 33.00 & 9.70 & 34.92 & 112.32 & 30.46 & 79.32 & 683.18 \\
\hline 6 years & 4.69 & 37.68 & 11.30 & 40.68 & 153.00 & 35.99 & 115.32 & 767.88 \\
\hline 7 years & 4.96 & 42.64 & 13.20 & 47.52 & 200.52 & 42.56 & 157.88 & 858.31 \\
\hline 8 years & 5.27 & 47.92 & 15.40 & 55.44 & 255.96 & 50.17 & 208.04 & 951.39 \\
\hline 9 years & 5.63 & 53.55 & 17.90 & 64.44 & 320.40 & 58.81 & 266.85 & 1044.55 \\
\hline 10 years & 6.06 & 59.60 & 20.90 & 75.24 & 395.64 & 69.18 & 336.04 & 1141.84 \\
\hline 11 years & 6.56 & 66.16 & 24.40 & 87.84 & 483.48 & 81.28 & 417.32 & 1239.28 \\
\hline 12 years & 7.14 & 73.31 & 28.50 & 102.60 & 586.08 & 95.46 & 512.77 & 1336.08 \\
\hline 13 years & 7.83 & 81.14 & 33.30 & 119.88 & 705.96 & 112.05 & 624.82 & 1431.00 \\
\hline 14 years & 8.62 & 89.75 & 38.80 & 139.68 & 845.64 & 131.06 & 755.89 & 1521.19 \\
\hline 15 years & 9.54 & 99.30 & 45.30 & 163.08 & 1008.72 & 153.54 & 909.42 & 1608.64 \\
\hline 16 years & 10.62 & 109.91 & 52.80 & 190.08 & 1198.80 & 179.46 & 1088.89 & 1690.53 \\
\hline 17 years & 11.89 & 121.80 & 61.70 & 222.12 & 1420.92 & 210.23 & 1299.12 & 1768.55 \\
\hline 18 years & 13.34 & 135.15 & 71.90 & 258.84 & 1679.76 & 245.50 & 1544.61 & 1839.68 \\
\hline 19 years & 15.06 & 150.20 & 83.90 & 302.04 & 1981.80 & 286.98 & 1831.60 & 1905.75 \\
\hline 20 years & 17.07 & 167.28 & 98.00 & 352.80 & 2334.60 & 335.73 & 2167.32 & 1966.42 \\
\hline
\end{tabular}

Source: compiled by the authors.

The results of calculations (Table 8) show that under the Assumptions 4.1 and 4.2 made in the 2 nd year of the garden a positive profitability of $463.54 \%$ is achieved (item 9), as well as a return of all invested funds and profit from activities in the amount of EUR1770 (item 8). At the same time, the average profitability increases after reaching its positive value of $86 \%$ per year until the age of 20 , and reaches the value of $1,966 \%$ in the 20th year of the garden. At the same time, the profitability of the enterprise in the 14th year becomes equal to profitability of the enterprise in the previous situation, and then it begins to lag behind, so that in the 20th year, the profit margin is already $2674 \%$. However, in the first 14 years, the given model still has significant advantages in gaining profit.

When analyzing the profitability of small and medium-sized businesses, it is also advisable to determine profitability at the processing level. At the processing level, the processor buys the walnut kernel, processes and sells oilcake and walnut oil in bulk according to B2B model.

Profitability of production (farm level): model 3, when the processor buys walnuts and sells oil and oilcake.

Assumption 5:

- In the first year of activity, the enterprise spends money on the establishment of production;

- Unshelled walnut is purchased for production;

- The cost of primary walnut processing (shelling and sorting) is not taken into account;

- Productivity of the equipment is $80 \mathrm{t}$ per year of processed raw materials or $33.6 \mathrm{t}$ of walnut oil and $38.4 \mathrm{t}$ of oilcake due to the fact that the number of working days per year is 250 w.d./year, or $4.000 \mathrm{~h}$ (production is performed in two shifts);

- Kernel output under primary walnut processing is $45 \%$; therefore, to obtain $80 \mathrm{t}$ of walnut kernel, it is necessary to purchase $180 \mathrm{t}$ of unshelled walnut fruits.

- When applying the given implementation form (Table 9).

The profitability of production in the first year is $267.62 \%$ (item 9), which enables to obtain higher profits than under other initial conditions during the period from 12 to 16 years. Production ensures the return of initial investments in the first year of work and profit in the amount of EUR460,000 (item 7). Profit remains higher than under other initial conditions during the period from 8 to 11 years. 
Table 9. Analysis of profitability of walnut processing into oil and oilcake when purchasing raw materials.

\begin{tabular}{|c|c|c|c|c|c|c|c|c|}
\hline $\begin{array}{l}\text { Year of the } \\
\text { Project Imple- } \\
\text { mentation }\end{array}$ & $\begin{array}{c}\text { Expenses, } \\
\text { Thousand } \\
\text { EUR }\end{array}$ & $\begin{array}{l}\text { Expenses of the } \\
\text { Progressive Total, } \\
\text { Thousand EUR }\end{array}$ & $\begin{array}{c}\text { Volume } \\
\text { of Raw } \\
\text { Materials, } \\
t\end{array}$ & $\begin{array}{l}\text { Income, } \\
\text { Thousand } \\
\text { EUR }\end{array}$ & $\begin{array}{l}\text { Income of the } \\
\text { Progressive Total, } \\
\text { Thousand EUR }\end{array}$ & $\begin{array}{l}\text { Profit, } \\
\text { Thousand } \\
\text { EUR }\end{array}$ & $\begin{array}{c}\text { Profit of the } \\
\text { Progressive Total, } \\
\text { Thousand EUR }\end{array}$ & $\begin{array}{c}\text { Profitability, } \\
\%\end{array}$ \\
\hline 1 year & 188.01 & 204.31 & 180 & 648 & 648 & 459.99 & 459.99 & 244.66 \\
\hline 2 years & 176.27 & 380.57 & 180 & 648 & 1296 & 471.73 & 931.72 & 267.62 \\
\hline 3 years & 176.27 & 556.84 & 180 & 648 & 1944 & 471.73 & 1403.45 & 267.62 \\
\hline 4 years & 176.27 & 733.11 & 180 & 648 & 2592 & 471.73 & 1875.19 & 267.62 \\
\hline 5 years & 176.27 & 909.37 & 180 & 648 & 3240 & 471.73 & 2346.92 & 267.62 \\
\hline 6 years & 176.27 & 1085.64 & 180 & 648 & 3888 & 471.73 & 2818.65 & 267.62 \\
\hline 7 years & 176.27 & 1261.91 & 180 & 648 & 4536 & 471.73 & 3290.39 & 267.62 \\
\hline 8 years & 176.27 & 1438.17 & 180 & 648 & 5184 & 471.73 & 3762.12 & 267.62 \\
\hline 9 years & 176.27 & 1614.44 & 180 & 648 & 5832 & 471.73 & 4233.85 & 267.62 \\
\hline 10 years & 176.27 & 1790.71 & 180 & 648 & 6480 & 471.73 & 4705.59 & 267.62 \\
\hline 11 years & 176.27 & 1966.97 & 180 & 648 & 7128 & 471.73 & 5177.32 & 267.62 \\
\hline 12 years & 176.27 & 2143.24 & 180 & 648 & 7776 & 471.73 & 5649.05 & 267.62 \\
\hline 13 years & 176.27 & 2319.51 & 180 & 648 & 8424 & 471.73 & 6120.79 & 267.62 \\
\hline 14 years & 176.27 & 2495.77 & 180 & 648 & 9072 & 471.73 & 6592.52 & 267.62 \\
\hline 15 years & 176.27 & 2672.04 & 180 & 648 & 9720 & 471.73 & 7064.25 & 267.62 \\
\hline 16 years & 176.27 & 2848.31 & 180 & 648 & 10368 & 471.73 & 7535.99 & 267.62 \\
\hline 17 years & 176.27 & 3024.57 & 180 & 648 & 11016 & 471.73 & 8007.72 & 267.62 \\
\hline 18 years & 176.27 & 3200.84 & 180 & 648 & 11664 & 471.73 & 8479.45 & 267.62 \\
\hline 19 years & 176.27 & 3377.11 & 180 & 648 & 12312 & 471.73 & 8951.19 & 267.62 \\
\hline 20 years & 176.27 & 3553.37 & 180 & 648 & 12960 & 471.73 & 9422.92 & 267.62 \\
\hline
\end{tabular}

Source: compiled by the authors.

The results of calculations in the comparative analysis of various models and implementation forms when implementing the project on the production and processing of walnuts in the oil and fat sub-complex are given in Table 10.

Table 10. Results of realization of various models and implementation forms when implementing the project on walnut production and processing.

\begin{tabular}{|c|c|c|c|c|c|c|c|c|}
\hline \multirow{3}{*}{$\begin{array}{l}\text { Year of the } \\
\text { Project Imple- } \\
\text { mentation }\end{array}$} & \multicolumn{6}{|c|}{ Model 2} & & \\
\hline & \multicolumn{2}{|c|}{ Model 1} & \multicolumn{2}{|c|}{ Implementation Form 1} & \multicolumn{2}{|c|}{$\begin{array}{l}\text { Implementation } \\
\text { Form } 2\end{array}$} & \multicolumn{2}{|c|}{ Model 3} \\
\hline & $\begin{array}{l}\text { Profit of the } \\
\text { Progressive } \\
\text { Total, } \\
\text { Thousand } \\
\text { EUR }\end{array}$ & $\begin{array}{c}\text { Profitability, } \\
\%\end{array}$ & $\begin{array}{l}\text { Profit of the } \\
\text { Progressive } \\
\text { Total, } \\
\text { Thousand } \\
\text { EUR }\end{array}$ & $\begin{array}{c}\text { Profitability, } \\
\%\end{array}$ & $\begin{array}{l}\text { Profit of the } \\
\text { Progressive } \\
\text { Total, } \\
\text { Thousand } \\
\text { EUR }\end{array}$ & $\begin{array}{c}\text { Profitability, } \\
\%\end{array}$ & $\begin{array}{l}\text { Profit of the } \\
\text { Progressive } \\
\text { Total, } \\
\text { Thousand } \\
\text { EUR }\end{array}$ & $\begin{array}{c}\text { Profitability, } \\
\%\end{array}$ \\
\hline 1 year & -16.3 & -100 & -16.3 & -100 & -16.30 & -100.00 & 459.99 & 244.66 \\
\hline 2 years & -6.25 & 332.06 & -12.95 & 17.96 & 1.77 & 463.54 & 931.72 & 267.62 \\
\hline 3 years & 5.9 & 395.09 & 5.69 & 269.2 & 23.24 & 525.35 & 1403.45 & 267.62 \\
\hline 4 years & 20.64 & 484.81 & 28.64 & 331.17 & 48.86 & 601.62 & 1875.19 & 267.62 \\
\hline 5 years & 38.36 & 579.2 & 56.62 & 403.32 & 79.32 & 683.18 & 2346.92 & 267.62 \\
\hline 6 years & 59.49 & 684.72 & 90.35 & 485.57 & 115.32 & 767.88 & 2818.65 & 267.62 \\
\hline 7 years & 84.63 & 799.09 & 130.91 & 582.96 & 157.88 & 858.31 & 3290.39 & 267.62 \\
\hline 8 years & 114.4 & 921.12 & 179.38 & 695.35 & 208.04 & 951.39 & 3762.12 & 267.62 \\
\hline 9 years & 149.48 & 1070.78 & 236.84 & 822.57 & 266.85 & 1044.55 & 4233.85 & 267.62 \\
\hline 10 years & 190.92 & 1237.2 & 305.08 & 974.56 & 336.04 & 1141.84 & 4705.59 & 267.62 \\
\hline 11 years & 239.76 & 1416.57 & 385.89 & 1150.93 & 417.32 & 1239.28 & 5177.32 & 267.62 \\
\hline 12 years & 297.16 & 1564.14 & 481.45 & 1356.27 & 512.77 & 1336.08 & 5649.05 & 267.62 \\
\hline 13 years & 364.71 & 1779.39 & 594.26 & 1594.94 & 624.82 & 1431.00 & 6120.79 & 267.62 \\
\hline 14 years & 443.92 & 2010.39 & 726.83 & 1866.15 & 755.89 & 1521.19 & 6592.52 & 267.62 \\
\hline 15 years & 536.9 & 2274.03 & 882.77 & 2183.59 & 909.42 & 1608.64 & 7064.25 & 267.62 \\
\hline 16 years & 645.79 & 2561.69 & 1065.67 & 2545.79 & 1088.89 & 1690.53 & 7535.99 & 267.62 \\
\hline 17 years & 773.58 & 2885.48 & 1280.55 & 2970.03 & 1299.12 & 1768.55 & 8007.72 & 267.62 \\
\hline 18 years & 923.04 & 3237.86 & 1532.1 & 3448.96 & 1544.61 & 1839.68 & 8479.45 & 267.62 \\
\hline 19 years & 1098.01 & 3635.65 & 1826.77 & 4002.71 & 1831.60 & 1905.75 & 8951.19 & 267.62 \\
\hline 20 years & 1302.98 & 4078.77 & 2172.13 & 4640.32 & 2167.32 & 1966.42 & 9422.92 & 267.62 \\
\hline
\end{tabular}

Source: developed/compiled by the authors.

According to Table 10 data, the model of walnut processing has several advantages, and its properties can significantly outweigh the disadvantages when considering the functioning of the implementation form. The income earned in the first 20 years of the project implementation in the oil and fat sub-complex for walnut processing in accordance with model 1 and model 2 has the order of about 103, while project implementation according to model 3 provides the order of income of almost 104. It should be noted that even under tougher restrictions imposed in the initial conditions of model 3 , this order does 
not change, which indicates the high efficiency of this approach. Changes in the income of the project under different models are shown in Figure 2a,b.

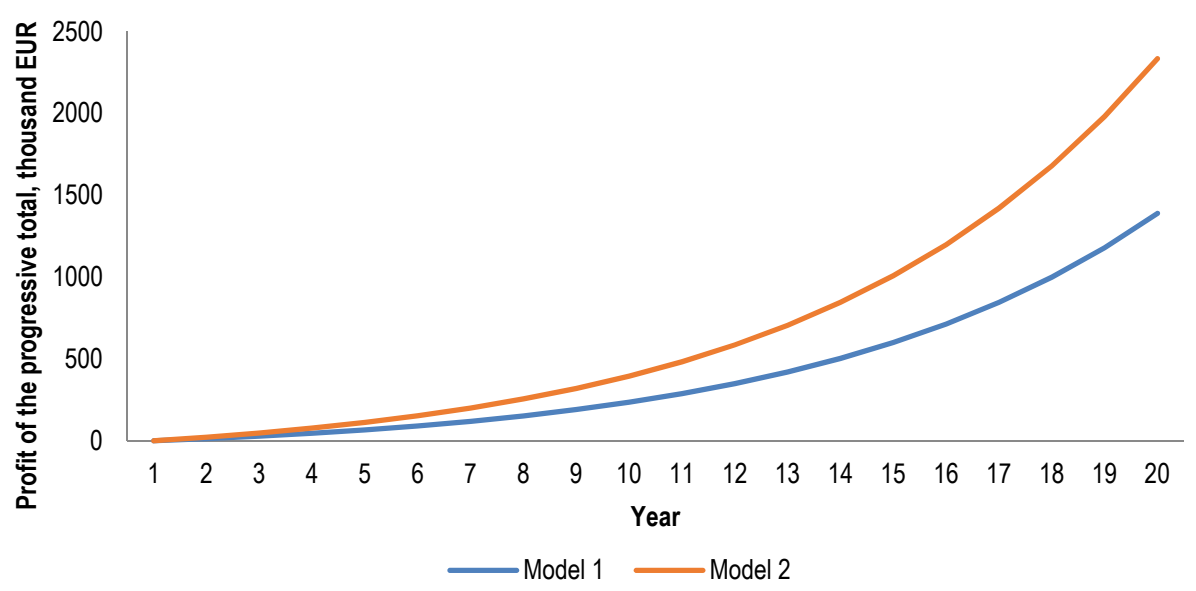

(a)

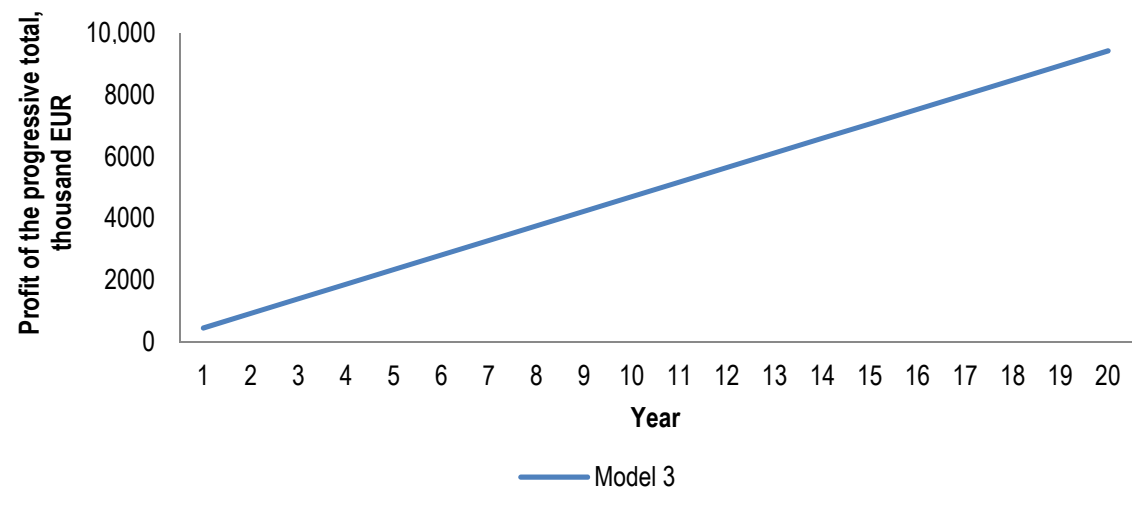

(b)

Figure 2. Revenue from the project implementation: (a) for models 1 and 2; (b) for model 3. Source: developed by the authors.

According to Table 11, the most cost-effective is the combination of walnut production and its processing, which will provide profitability of up to $4640.32 \%$ in the 20 th year of the project implementation. In addition, such an approach has a number of strategic advantages, which are based on production diversification and reduction in operational risks. However, it is necessary to take into consideration a number of factors that were not displayed in the given models, especially marketing ones [55]. Their inclusion will enable to optimize production, increase added value, and develop a competitive strategy when exporting products. 
Table 11. The main indicators of models of the project implementation in the oil and fact sub-complex for walnut processing.

\begin{tabular}{cccccc}
\hline & \multicolumn{5}{c}{ Indicators } \\
\cline { 2 - 6 } Models & $\begin{array}{c}\text { Year of } \\
\text { Achieving a } \\
\text { Positive } \\
\text { Profit }\end{array}$ & $\begin{array}{c}\text { Year of } \\
\text { Investment } \\
\text { Return }\end{array}$ & $\begin{array}{c}\text { Average } \\
\text { Profitability } \\
\text { Over } \\
\text { 20 Years, \% }\end{array}$ & $\begin{array}{c}\text { Average } \\
\text { Increase in } \\
\text { Profitability } \\
\text { Per Year over } \\
\text { 20 Years, \% }\end{array}$ & $\begin{array}{c}\text { Profitability } \\
\text { in the 20th } \\
\text { Year }\end{array}$ \\
\hline $\begin{array}{c}\text { Model 1 } \\
\text { Model 2 }\end{array}$ & 2 & 3 & 1592.40 & 174.98 & 4078.77 \\
$\begin{array}{c}\text { Implementation } \\
\text { form 1 }\end{array}$ & 2 & 3 & 1512.18 & 211.85 & 4640.32 \\
$\begin{array}{c}\text { Implementation } \\
\text { form 2 } \\
\text { Model 3 }\end{array}$ & 2 & 2 & 1162.24 & 64.16 & 1966.42 \\
\hline Source: developed/compiled by authors. & 1 & 266.47 & 1.15 & 267.62 \\
\hline
\end{tabular}

\section{Discussion}

As shown by the studies presented in [34,35], sub-complex of deep walnut processing produces walnut kernels for the confectionary industry and for animal feeding, food walnut oil, industrial oil and oilcake, that can be processed in to the food products or used for animal feeding as well at global and foreign markets. Sub-complex produces residuals, that can be used for biofuel production or be the raw materials for other industries. Walnut fruits are deemed as a product of the sub-complex. Other walnut derivative products are being investigated currently. Among them are such products as: walnut shell [19], organic walnut kernel [27], walnut kernels mixed with wild honey [28], jaggery coated walnut kernels and honey glazed walnut kernels [31], green walnut [36], derivative produces that allows to receive complementary benefits from walnut (anti-ageing, improving of skin quality, treatment of psoriasis, treatment of skin infection, treatment of eczema, healing qualities) [37], by-products of walnut, such as green husk and walnut shell [38]. The given study emphasizes walnut fruits, confectionary kernels and oil.

Our research proves that the implementation of model 3 enables to provide profitability of $244.66 \%$ in the first year and $267.62 \%$ in the second year. By the closest value of this indicator in the model, this level of profitability can be achieved no earlier than the second year, and by implementation form 1 of model 2 only in 3 years. Thus, in the short-term prospect this model can be treated as the most rational one.

In the future, the proposed model can be improved due to the consideration of additional factors and conditions [3]:

- It is expedient to process walnut in accordance with its grade, since the confectionery walnut can be sold at a fairly high price without additional costs for further processing;

- The profitability of the enterprise will be higher than in the proposed model if the sale price of walnut oil cake is taken into account;

- Profitability of the enterprise will be higher if walnut shell is processed into biofuel or food for animal feeding and sold;

- The increase in production capacity will lead to the increase in the income of the enterprise;

- Development of B2B model into B2C model, development of the individual innovative functional food products from walnuts fruits, and access to the consumer market with its individual trademark can significantly increase the profitability of production. In this case, the cost analysis should be supplemented by the marketing costs, in particular, for sales. 


\section{Conclusions}

As a result of the analysis of profitability of the enterprises of oil and fat sub-complex for deep walnut processing, it can be concluded that the enterprise is highly profitable, according to the obtained data, due to obtaining the added gross profit. Profitability is higher when a farmer increases value added and sells walnut oil and cake. The passive growth of profitability of walnut farms can be caused by an increase in the current price for walnut kernel and products of its processing. The active development of the business is possible through the creation of its own brand, entering the consumer market and use of the B2C model.

To achieve the set goals, the approach of the sub-complex analysis was used, which has given an opportunity to obtain a systematic view of the various stages of interaction associated with the creation of products beginning with the procurement of raw materials and ending with the production of consumer goods. This approach enables to obtain results that are useful for both the participants of the agro-food value chain at different levels and subjects engaged in decision-making. Thus, the sub-complex analysis approach provides the basis for sectoral actions. The prospect of the agro-food chain ensures that these actions will not be limited by the local level. This will facilitate relations with the global (internal) economy. Such relations include infrastructure improvement, affordability of loans, marketing tools, and a range of services required for trade.

Author Contributions: Conceptualization, V.L., T.H.; methodology, N.K., Z.K.; database creation, S.B.; literature review, T.M.; funding acquisition, D.K. All authors have read and agreed to the published version of the manuscript.

Funding: Own Scientific Foundation University of Agriculture in Krakow.

Institutional Review Board Statement: Not applicable.

Informed Consent Statement: Not applicable.

Data Availability Statement: Not applicable.

Conflicts of Interest: The authors declare no conflict of interest.

\section{References}

1. International Nuts\&Dried Fruit. Nuts \& Dried Fruits Global Statistical Review 2015/2016. 2016. Available online: https: / / www.nutfruit.org/files/tech/Global-Statistical-Review-2015-2016.pdf (accessed on 15 November 2021).

2. Statista. Production of Major Vegetable Oils Worldwide from 2012/13 to 2017/2018, by Type (in Million Metric Tons). 2018 . Available online: https://www.statista.com/statistics/263933/production-of-vegetable-oils-worldwide-since-2000/ (accessed on 15 November 2021).

3. Lutsiak, V.; Lavrov, R.; Furman, I.; Smitiukh, A.; Mazur, H.; Zahorodnia, N. Economic Aspects and Prospects for the Development of the Market of Vegetable Oils in a Context of Formation of its Value Chain. Montenegrin J. Econ. 2020, 16, 155-168. [CrossRef]

4. Lyulyov, O.; Chortok, Y.; Pimonenko, T.; Borovik, O. Ecological and economic evaluation of transport system func-tioning according to the territory sustainable development. Int. J. Ecol. Dev. 2015, 30, 1-10.

5. Kachel, M.; Matwijczuk, A.; Przywara, A.; Kraszkiewicz, A.; Koszel, M. Profile of Fatty Acids and Spectroscopic Characteristics of Selected Vegetable Oils Extracted by Cold Maceration. Agric. Eng. 2018, 22, 61-71. [CrossRef]

6. Botta, R.; Molnar, T.J.; Erdogan, V.; Valentini, N.; Marinoni, D.T.; Mehlenbacher, S.A. Hazelnut (Corylus spp.) Breeding., Advances in Plant Breeding Strategies: Nut and Beverage Crops, 157-219. 2019. Available online: https://link.springer.com/chapter/10.1 007/978-3-030-23112-5_6 (accessed on 15 November 2021).

7. Ferrão, A.C.; Guiné, R.; Rodrigues, M.; Droga, R.; Correia, P. Post-harvest characterization of the hazelnut sector. Agric. Food Vet. Sci. 2020, 6, 11-20.

8. Jung, J.; Wang, W.; McGorrin, R.J.; Zhao, Y. Moisture Adsorption Isotherm and Storability of Hazelnut Inshells and Kernels Produced in Oregon, USA. J. Food Sci. 2018, 83, 340-348. [CrossRef]

9. Pena, I.A.; Lucas, I.L.; Penna-Firme, R.; Strassburg, B.; Drosik, A.; Rubisz, L.; Kubon, M.; Latala, H.; Grotkiewicz, K.; Kubon, K.; et al. Survey-Based Qualitative Analysis of Young Generation Perception of Sustain-able Development in Poland. Agric. Eng. 2020, 24, 75-86. [CrossRef]

10. Bachev, H.B.H. Risk Management in the Agri-food Sector. Contemp. Econ. 2013, 7, 45-62. [CrossRef]

11. Bozhok, O.; Bozhok, V. Pro perspektyvy vyroshchuvannia horikha hretskoho na terytorii Ukrainy [On the pro-spects for growing walnut on the territory of Ukraine]. Naukovyi Visnyk NLTU Ukrainy 2017, 27, 25-29. 
12. Kubon, M.; Krasnodebski, A. Logistic costs in competitive strategies of enterprises. Agric. Econ. 2010, 56, 397-402. [CrossRef]

13. Mishenin, Y.; Koblianska, I.; Medvid, V.; Maistrenko, Y. Sustainable regional development policy formation: Role of industrial ecology and logistics. Entrep. Sustain. Issues 2018, 6, 329-341. [CrossRef]

14. Grotkiewicz, K.; Peszek, A.; Obajtek, P. Supply Chain Management in a Production Company. Agric. Eng. 2019, 23, 61-69. [CrossRef]

15. Gaura, M.; Kuboń, M.; Kowalczyk, Z.; Kwaśniewski, D.; Daniel, Z.; Kapela, K. Quality Assessment of Delivery in the Supply Chain Optimization. Agric. Eng. 2020, 24, 21-30. [CrossRef]

16. Poggetti, L.; Ferfuia, C.; Chiabà, C.; Testolin, R.; Baldini, M. Kernel oil content and oil composition in walnut (Ju-glans regia L.) accessions from north-eastern Italy. J. Sci. Food Agric. 2018, 98, 955-962. [CrossRef]

17. Jahanban-Esfahlan, A.; Jahanban-Esfahlan, R.; Tabibiazar, M.; Roufegarinejad, L.; Amarowicz, R. Recent advances in the use of walnut (Juglans regia L.) shell as a valuable plant-based bio-sorbent for the removal of hazardous materials. RSC Adv. 2020, 10, 7026-7047. [CrossRef]

18. Yermakov, S.; Hutsol, T.; Glowacki, S.; Hulevskyi, V.; Pylypenko, V. Primary assessment of the degree of torrefaction of biomass agricultural crops. In Environment. Technology. Resources, Proceedings of the International Scientific and Practical Conference; Rezekne Academy of Technologies, Rezekne, Latvia, 17-18 June 2021; 2021; Volume 1, pp. 264-267. Available online: http: / / elar.tsatu.edu.ua / handle/123456789/14974 (accessed on 15 November 2021).

19. Deng, X.L.; Zhao, Q.Z. Study on conformation and functional properties of walnut protein and its components. Mod. Food Sci. Technol. 2017, 33, 48-53.

20. Lisiecka, K.; Wójtowicz, A. The Production Efficiency and Specific Energy Consumption During Processing of Corn Extrudates with Fresh Vegetables Addition. Agric. Eng. 2019, 23, 15-23. [CrossRef]

21. Niemiec, M.; Komorowska, M.; Szelag-Sikora, A.; Sikora, J.; Kuboń, M.; Gródek-Szostak, Z.; Kapusta-Duch, J. Risk Assessment for Social Practices in Small Vegetable farms in Poland as a Tool for the Optimization of Quality Management Systems. Sustainability 2019, 11, 3913. [CrossRef]

22. Davis, D.R.; Weinstein, D.E. Economic geography and regional production structure: An empirical investigation. Eur. Econ. Rev. 1999, 43, 379-407. [CrossRef]

23. Ferrantino, M.J. Using Supply-Chain Analysis to Analyse the Costs of NTMs and the Benefits of Trade Facilitation. Available online: https://ideas.repec.org/p/zbw/wtowps/ersd201202.html (accessed on 15 November 2021).

24. Nang'ole, E.; Mithöfer, D.; Franzel, S. Review of Guidelines and Manuals for Value Chain Analysis for Agricultural and Forest Products. ICRAF Occasional Paper No. 17. Nairobi: World Agroforestry Centre. 2011. Available online: http:/ /www. worldagroforestry.org/downloads/Publications/PDFS/OP11160.pdf (accessed on 15 November 2021).

25. The European Union for Georgia. Walnut Value Chain Analysis in Ajara Region of Georgia. Tbilisi. 2016. Available online: http:/ / environment.cenn.org/app/uploads/2017/04/Walnut-VCA-Report-eng.pdf (accessed on 15 November 2021).

26. Qammer, N. Analysis of Modernized Value Chain of Walnut in Jammu \& Kashmir. Econ. Aff. 2018, 63, 165-174. [CrossRef]

27. Bourne, W. Analysis of the Walnut Value Chain in the Kyrgyz Republic Working Paper. Washington D.C: PROFOR. 2012. Available online: https://www.profor.info/sites/profor.info/files/Walnut_Value_Chain_KyrgyzRepublic_0.pdf (accessed on 15 November 2021).

28. Pandey, G.; Shukla, S.K. The Walnut Industry in India-Current Status and Future Prospects. Int. J. Fruit Sci. 2007, 6, 67-75. [CrossRef]

29. Szelagg-Sikora, A.; Sikora, J.; Niemiec, M.; Gródek-Szostak, Z.; Kapusta-Duch, J.; Kuboń, M.; Komorowska, M.; Karcz, J. Impact of Integrated and Conventional Plant Production on Selected Soil Parameters in Carrot Production. Sustainability 2019, $11,5612$. [CrossRef]

30. Sharma, P.; Naik, H.R.; Hussain, S.Z.; Rouf, A. Development and popularization of broken walnut kernels products. Pharma Innov. J. 2019, 8, 475-476.

31. Scherer, F.M.; Ross, D. Industrial Market Structure and Economics Performance; Houghton Mifflin Company: Boston, MA, USA, 1990.

32. World Trade Organization. Technological Innovation, Supply Chain Trade, and Workers in a Globalized World. Global Value Chain Development Report 2019. 2019. Available online: https:/ / www.oecd.org/dev/Global-Value-Chain-Development-Report2019-Technological-Innovation-Supply-Chain-Trade-and-Workers-in-a-Globalized-World.pdf (accessed on 15 November 2021).

33. Jokić, S.; Moslavac, T.; Bošnjak, A.; Aladić, K.; Rajić, M.; Bilić, M. Optimization of walnut oil production. Croat. J. Food Sci. Technol. 2014, 6, 27-35.

34. Global Industry Analysts. Vegetable Oils-A Global Strategic Business Report. Press Relese. 2020. Available online: https: / / www.strategyr.com/pressMCP-2226.asp (accessed on 15 November 2021).

35. Jaćimović, V.; Adakalić, M.; Ercisli, S.; Božović, D.; Bujdoso, G. Fruit Quality Properties of Walnut (Juglans regia L.) Genetic Resources in Montenegro. Sustainability 2020, 12, 9963. [CrossRef]

36. Mir, G.; Owais, N.; Uzma, I. Scientific Processing of Walnuts Necessary for Amazing Health Benefits. J. Chem. Chem. Sci. 2016, 6, 783-793.

37. Liu, M.; Li, C.; Cao, C.; Wang, L.; Li, X.; Che, J.; Yang, H.; Zhang, X.; Zhao, H.; He, G.; et al. Walnut Fruit Processing Equipment: Academic Insights and Perspectives. Food Eng. Rev. 2021, 13, 822-857. [CrossRef]

38. Radko, V. The Economic Aspects of Planting and Operation of the Greek Garden. Available online: https://uhbdp.org/images/ uhbdp/pdf/Plodoov_vo_2016/1.3_Nuts.pdf (accessed on 15 November 2021). 
39. Lanovenko, V. Golden Nut: How to Make Good in-Vestments in Walnut. 2016. Available online: http://agravery.com/en/posts/ show / zolotij-gorisok-ak-vigidno-investuvati-u-voloskijgogih (accessed on 15 November 2021).

40. Verma, M.K. Walnut Production Technology. 2014. Available online: https://www.researchgate.net/publication/282365700_ Walnut_Production_Technology (accessed on 15 November 2021).

41. Wen, K.; Liang, S.L.; Yao, Z.Q.; Hao, H.; Liu, Z.L. Study on the processing technology of high protein defatted walnut powder. Sci. Technol. Food Ind. 2009, 12, 273-276.

42. Tabasi, M.; Sheidai, M.; Hassani, D.; Koohdar, F. DNA fingerprinting and genetic diversity analysis with SCoT markers of Persian walnut populations (Juglans regia L.) in Iran. Genet. Resour. Crop. Evol. 2020, 67, 1437-1447. [CrossRef]

43. Zhu, T.; Wang, L.; You, F.M.; Rodriguez, J.C.; Deal, K.R.; Chen, L.; Li, J.; Chakraborty, S.; Balan, B.; Jiang, C.-Z.; et al. Sequencing a Juglans regia $\times$ J. microcarpa hybrid yields high-quality genome assemblies of parental species. Hortic. Res. 2019, 6, 1-16. [CrossRef]

44. Perederiy, N.K.; Kuzmenko, S.; Labenko, O. Energy-saving technologies in agriculture of ukraine. Metod. Ilościowe Bad. Ekon. 2016, 17, 89-100. [CrossRef]

45. Pu, C.W.; Kan, H.; Liu, Y. Comparative study of different walnut peeling processes. Farm Prod. Process. 2017, 11, 33-35.

46. Wang, L.; Wang, Y.Q.; Chai, X.T.; Liu, M.K.; Liu, X.Z.; Li, J.; Gan, S.Y. Peeling of walnut kernel by vacuum freeze-drying: An analytical and experimental study. Chin. J. Vac. Sci. Technol. 2019, 39, 103-106.

47. Asgari, K.; Labbafi, M.; Khodaiyan, F.; Kazemi, M.; Hosseini, S.S. Valorization of walnut processing waste as a novel resource: Production and characterization of pectin. J. Food Process. Preserv. 2020, 44. [CrossRef]

48. Mudryk, K.; Hutsol, T.; Wrobel, M.; Jewiarz, M.; Dziedzic, B. Determination of friction coefficients of fast-growing tree biomass. Eng. Rural. Dev. 2019. [CrossRef]

49. Kovalenko, N.; Kovalenko, V.; Hutsol, T.; Ievstafiieva, Y.; Polishchuk, A. Economic Efficiency and Internal Competitive Advantages of Grain Production in the Central Region of Ukraine. Agric. Eng. 2021, 25, 51-62. [CrossRef]

50. Kovalenko, V. Economic Basis for the Creation of Fodder Base of the Enterprise. In Proceedings of the International Scientific Days 2018. Towards Productive, Sustainable and Resilient Global Agriculture and Food Systems: Proceedings, Nitra, Slovakia, 16-17 May 2018; pp. 840-850.

51. Kovalenko, V.; Hutsol, T.; Kovalenko, N.; Zasada, M. Economic efficiency of production of herbal granules. Tur. Rozw. Reg. 2020, 14, 127-135. [CrossRef]

52. Perederiy, N. Experience in financial planning in European countries. Sci. Bull. Natl. Univ. Life Eviron. Sci. Ukr. 2013, 181, 78-82.

53. Prishlyak, N. The experience of walnuts pro-duction in the world. Ekonomika. Finansy. Menedzhment Curr. Issues Sci. Pract. 2017, 1, 63-72.

54. Kotler, P. Relationship Marketing: Kotler on Marketing. 2014. Available online: http://www.marsdd.com/mars-library/ relationship-marketing-kotler-on-marketing/ (accessed on 15 November 2021).

55. Akca, Y.; Bilgen, Y.; Ercisli, S. Selection of superior persian walnut (Juglans regia L.) from seedling origin in Tur-key. Acta Sci. Pol. Hortorum Cultus 2015, 14, 103-114.

56. Avanzato, D. Traditional And Modern Uses Of Walnut. Acta Hortic. 2010, 861, 89-96. [CrossRef]

57. Gajanana, T.M. Marketing practices and post-harvest loss assessment of banana var. Poovan in Tamil Nadu. Agric. Econ. Res. Rev. 2002, 15, 56-65.

58. Global Hazelnut Market—Growth, Trends and Forecast, 2019-2024. Available online: https://cutt.ly/Yg3tMrX (accessed on 15 November 2021).

59. Global Tree Nuts Market 2019-2023. 2021. Available online: https:/ / cutt.ly/6g3t1mR (accessed on 15 November 2021).

60. Hussain, S.Z.; Afshana, B.; Rather, A.H. Preparation and Storage Studies of Walnut Kernel Incorporated Rice Based Snacks. Int. J. Basic Appl. Biol. 2015, 2, 449-451.

61. Barkley, Y.C. Carpathian Walnut. Alternative Tree Crops Information Series, 5. 2007. Available online: https://www.uidaho.edu/ - / media/UIdaho-Responsive/Files / Extension/topic/ forestry / ATC5-Carpathian-walnut.pdf?la=en\&hash=94C07C90F1B070 356F62039CB95173ED9E2CA146 (accessed on 15 November 2021).

62. Ivanyshyn, V.; Sheludchenko, L.; Hutsol, T.; Rud, A.; Skorobogatov, D. Mass transfer management and deposition of contaminants within car road zones. Environ. Technol. Resour. Proc. Int. Sci. Pr. Conf. 2019, 1, 70-74. [CrossRef]

63. Minh, N.P.; Pha, P.T.L.; Trang, N.T.T. Effect of Drying and Roasting to Antioxidant Property and Stabil-ity of Dried Roasted Walnut (Juglans regia). J. Pharm. Sci. Res. 2019, 11, 1693-1697.

64. Market Overview of Hazelnut in Ukraine. Tridge.com: Website. Available online: https://www.tridge.com/products/hazelnutin-shell/UA (accessed on 15 November 2021).

65. Shifting Trends in Global Tree Nut Market. Available online: https://www.globalaginvesting.com/gai-gazette-shifting-trendsglobal-tree-nut-markets / (accessed on 15 November 2021).

66. Tree Nuts: World Markets and Trade. USDA. Available online: https:/ / cutt.ly/rg8YFjY (accessed on 15 November 2021). 